\title{
Accreditation Role of the National Universities Commission and the Quality of the Educational Inputs into Nigerian University System
}

\author{
Ibijola* , Elizabeth Yinka \\ Department of Educational Foundations and Management, Ekiti State University, Ado-Ekiti, Nigeria \\ *Corresponding Author: ibjemm@yahoo.com
}

Copyright (C) 2014 Horizon Research Publishing All rights reserved.

\begin{abstract}
The Accreditation role of the National Universities Commission (NUC) and the quality of the educational inputs into Nigerian university system was investigated in this work, using a descriptive research of survey design. The population consisted of public Universities in South-West, Nigeria. The sample was made up of 300 subjects, consisting of 50 staff members from six Universities sampled from the population. The findings of the study revealed a moderate level of NUC performance of its accreditation role, and a direct positive relationship with quality of inputs into Nigerian university system. Based on the findings of the study, conclusions were drawn and recommendation made that the National Universities Commission should improve on its accreditation role to improve on the quality of educational inputs into Nigeria university system.
\end{abstract}

Keywords Quality, Educational Inputs, National Universities Commission, Accreditation

\section{Introduction}

In the last decade according to Uvah (2005), "there has been increasing concern on the part of governments around the world that higher education in their countries be worthy of respect. In this connection, varying national approaches to quality assurance have been established. The multi-dimensional nature of quality assurance according to Awe (2009) probably inform the different approaches by various governments all over the world have for quality assurance, and at the moment there is no uniformity or harmonization of quality assurance agencies and their procedures. EL-Khawas (2006) wrote that there are currently more than 70 quality assessment agencies around the world, while ESIB (2005) indicated the existence of wide varieties of quality assurance agencies worldwide.

In Nigeria, the National Universities Commission (NUC) is the Federal government agency that has the power to accredit institutions and their academic programmes, and ensure proper monitoring of same for adequate adherence, be it federal, state or private universities. The NUC plays its roles in conjunction with some designated professional bodies and agencies that assess and accredit the professional contents of some programmes. Examples of such are the Nigerian Medical and Dental Council (NMD) that assesses and accredits the professional contents of medical programmes, the Institute of Charted Accountants of Nigeria (ICAN) that assesses and accredits the professional contents of Accounting programmes, the Council of Legal Education (CLE) that assesses and accredits the professional contents of Law programmes and the Council for Registration of Engineering in Nigeria (COREN) that assesses and accredits the professional contents of Engineering programmes in Nigerian Universities.

Accreditation according to Okebukola (2002) is the core component of quality assurance. Oladosu (2011) and NUC (2006) defined accreditation as a measure of quality of academic programmes while Woodhouse, (1999) defined accreditation as a yes or no decision. Consequently, accreditation is presumed to be an evaluation of whether an institution or programme meets a set of minimum academic standard and qualities for a certain status. Accreditation in the Nigerian university system according to Fadokun (2006) has three stated objectives: (i) to ensure that at least the provision of the Minimum Academic Standard (MAS) documents are attained, maintained and enhanced; (ii) to assure employers of labour and other members of the community that Nigerian graduates of all academic programmes have attained an acceptable level of competence in their areas of specializations and (iii) to certify to the international community that the programmes offered in Nigerian Universities are of high standards and their graduates are adequate for employment and for further studies.

On this premise, the National Universities Commission (NUC) on 1989 first developed the content-based Minimum 
Academic Standard (MAS) for the thirteen broad disciplines taught in the Nigerian Universities by setting up panels of experts in academics in these discipline and comments by Universities' Faculties and departments on the draft MAS produced by the panel were duly incorporated into the documents after which they were given formal approval by the Federal Government in July 1989 (Ramon-Yusuf, 2003). The Minimum Academic Standards (MAS) documents which the Commission produced in 1989 provided for minimum floor space for lecturers, minimum laboratory facilities per student, minimum library space, library holdings and their currency as well as minimum staff/student ratio for effective teaching and learning in any given discipline. It also stipulates a curriculum as well as minimum entry and graduation requirements for each discipline.

According to Uvah (2005) the NUC organized a Stakeholders Conference on Curriculum Review in April 2001 during which panels of experts, academics and professional bodies drew up panels of academics which incorporated comments of universities into the draft documents to produce national benchmarks. Subsequently, in 2004 according to Uvah, the Commission constituted teams of experts and academics to merge the Minimum Academic Standards (MAS) with the Benchmark Statements into a single document, the Benchmark-MAS for the different disciplines. These documents have been used and are being used by the NUC as benchmarks for accreditation as an external regulatory mechanism for enhancing quality in Nigerian universities (Uvah, 2005). However, Uvah further asserted that the Minimum Academic Standards are subject to review every five years in order to update them in line with technological advances and changing societal needs.

Although NUC (2007) defined quality assurance as a key component of successful internalization, mechanism for building institutional reputation in a competitive local and global arena and necessary foundation for consumer protection, most stakeholders in university education however make it appears the NUC is finding it difficult to achieve all these. Okwuofu and Aminu (2013) reported that the Academic Staff Union of Nigerian Universities (ASUU) claimed that "the NUC accreditation exercise, which gave a "controversial" clean bill of health to most universities in the country, were the result of what is called an un-ethical accreditation exercises because the NUC was alleged of regulating quantity instead of ensuring quality delivery'.

Subsequently, there have been series of complaints from the public domain about the accreditation exercise of the NUC and observations seem to be pointing towards the absence, utter disregard or failure of regulatory system within the Nigerian university system (Aboderin, 2012). In the absence of improved facilities to cope with increased demand for university education, many of the universities had to exceed their carrying capacities, which are defined as the maximum number of students that each university can sustain for qualitative education based on available human and material resources (NUC, 2005). The provision of adequate and quality physical infrastructure such as lecture theatres, laboratories, student hostels and residential quarters for teaching and non-teaching staff seem to have been replaced by overcrowded classes, resulting in poor quality teaching and research, examination malpractices and high lecturer/student ratio.

Amaka (2012) noted with concern the fraud and self-deception with regard to accreditation processes of the NUC as many states, without a proper assessment, establish university for ego and political reasons. Corroborating this view, Akinyanju (2012) asserted that the level of fraud that the NUC is over the years is evident in situations when department of Microbiology for instance is granted full accreditation in three different universities where there were 26 microscope available for a practical class of 150 students in ratio (1:6), 10 microscope to 220 students $(1: 22)$ and four (4) microscopes to a class of 100 students (1:25) respectively. This view is also supported by the Punch editorial comment (2013, August 16) which posited that those universities which otherwise could have failed necessary quality tests, were forced to be given approval because they are government-owned.

The NUC as the government regulatory agency mandated by law to act as a catalyst for positive change for the delivery of quality university education, has lost focus, (the Punch Editorial 2013, August 16) submitted. The report claimed that the NUC has bastardized and corrupted its accreditation exercise and consequently has lost focus. Okwuofu and Aminu (2013) reported that the Academic Staff Union of Universities has reiterated its call for the scrapping or an overhaul of the NUC. It is on this note that Ade-Ajayi (2003) advocated for an outright proscription of the NUC. According to Okwuofu and Aminu (2013)'s report, ASUU posited that the Commission has failed to reposition the nation's universities as shown by the NEEDS assessment report carried out by genuine academics, which contradicted the NUC's accreditation exercise. According to the report, ASUU claimed that 'the NUC accreditation exercise, which gave a 'controversial' clean bill of health to most universities in the country, were the result of what is called an un-ethical accreditation and that the NUC has allegedly been regulating quantity instead of ensuring quality delivery'.

Belo-Osagie (2012) reported that the NEEDS Assessment committee was shocked by the unsatisfactory quality and quantity of academics, poor state of hostels and toilet facilities, high number of abandoned projects, poor state of laboratories compared with the usually beautiful pictures painted by University administrators in their convocation speeches. Akinyanju (2012) submitted that Nigerian universities source for Internally Generated Revenue (IGR) by creating additional non-NUC vetted courses which are fee-paying. Consequently, "the non-abating crisis in the accreditation process of courses in the system is headlined by the fiasco that sees students graduating, only for the NUC to declare that it did not approve their courses (Atoyebi and Oyeleke, 2013). 


\section{Statement of the Problem}

It is a common knowledge today that products of accredited Nigerian institutions and their academic programmes are regarded as of low quality by most of the stakeholders in education. While most people attributed the cause to the poor accreditation mechanism of the NUC, some attributed it to the poor quality of the educational inputs. This situation calls for concern and in addressing the problems of the study therefore, the following general questions were raised to guide the study;

1. What is the federal universities' staff perception of the NUC accreditation role?

2. What is the state universities' staff perception of the NUC accreditation role?

3. What is the NUC level of performance of its accreditation role?

4. What is the level of quality of the educational inputs?

\section{Purpose of the Study}

The purpose of this study was to investigate the level of performance of the accreditation role of the National Universities Commission (NUC) and its relationship with the quality of educational inputs.

\section{Research Questions}

1. Is there any difference between the perception of Federal and State Universities' staff on NUC performance of its accreditation role?

2. Is there any relationship between NUC level of performance of its accreditation role and the quality of the educational inputs?

\section{Research Hypotheses}

1. There is no significant difference between the perception of Federal and State Universities' staff on NUC performance of its accreditation role.

2. There is no significant relationship between NUC level of performance of its accreditation role and the quality of the educational inputs.

\section{Research Method}

The study employed a descriptive research of the survey type. The population for the study consisted of the staff members of public universities in south-west Nigeria. The sample consisted of 300 staff members from six of the public universities ( 3 federal and 3 state universities) in south-west Nigeria. Purposive and simple random sampling techniques were used to select the sample. Data were collected using an instrument titled 'Accreditation Role of the National Universities Commission and Quality of educational inputs into Nigerian University system (ARQINUS)'. The instrument consisted of 46 items that elicited information on the performance of NUC accreditation roles and quality of educational inputs. The face and content validity of the instrument were carried out by specialists in Educational Management, and Test and Measurement in order to ensure that the instrument adequately measure the intended content areas of the study. The reliability of the instrument was ascertained using the split-half method. The split-half co-efficient was corrected to full-length co-efficient using the Spearman Brown prophecy formula with a reliability co-efficient of 0.88 . Data obtained from the instruments were analyzed using descriptive statistics to analyze the research question.

\section{Results and Discussion}

\section{Descriptive Analysis of Data}

Question 1: What is the federal universities' staff perception of the NUC accreditation role?

To answer this question, federal universities' respondents scores on NUC accreditation roles was computed using Section B of the 'ARQINUS' questionnaire. The mean scores and the standard deviation were used to categorize the subjects into three groups representing levels of performance. Using the mean score of 14.00 and standard deviation of 23.45, respondents whose scores ranged between the minimum scores of 14 and the difference between the mean and standard deviation (X-SD) were grouped into 'Low' level performance i.e. (14 - 23.45). Respondents whose scores ranged from the sum of mean and standard deviation and the maximum score of (41.00) were grouped as 'High' i.e. $(33.01-41.00)$. "The moderate' level of performance constituted the respondents whose scores fell between the 'low' and 'high' level (23.46-33.00). The findings revealed that the NUC performance of its accreditation role was at a moderate level with $80.0 \%$ of the respondents adjudging the NUC's performance as moderate. The result is presented in table 1 and graphically represented in figure 1 .

Table 1. Federal universities' staff perception of NUC performance of its accreditation role

\begin{tabular}{|c|c|c|}
\hline Level & f & \% \\
\hline $\begin{array}{c}\text { Low: Min-(x - SD) } \\
(\mathbf{1 4 . 0 0}-\mathbf{2 3 . 4 5 )}\end{array}$ & 17 & 11.3 \\
\hline Moderate: (23.46-33.00) & 120 & 80.0 \\
\hline $\begin{array}{c}\text { High: (x + SD) } \\
(\mathbf{3 3 . 0 1}-\mathbf{4 1 . 0 0 )}\end{array}$ & 13 & 8.7 \\
\hline
\end{tabular}




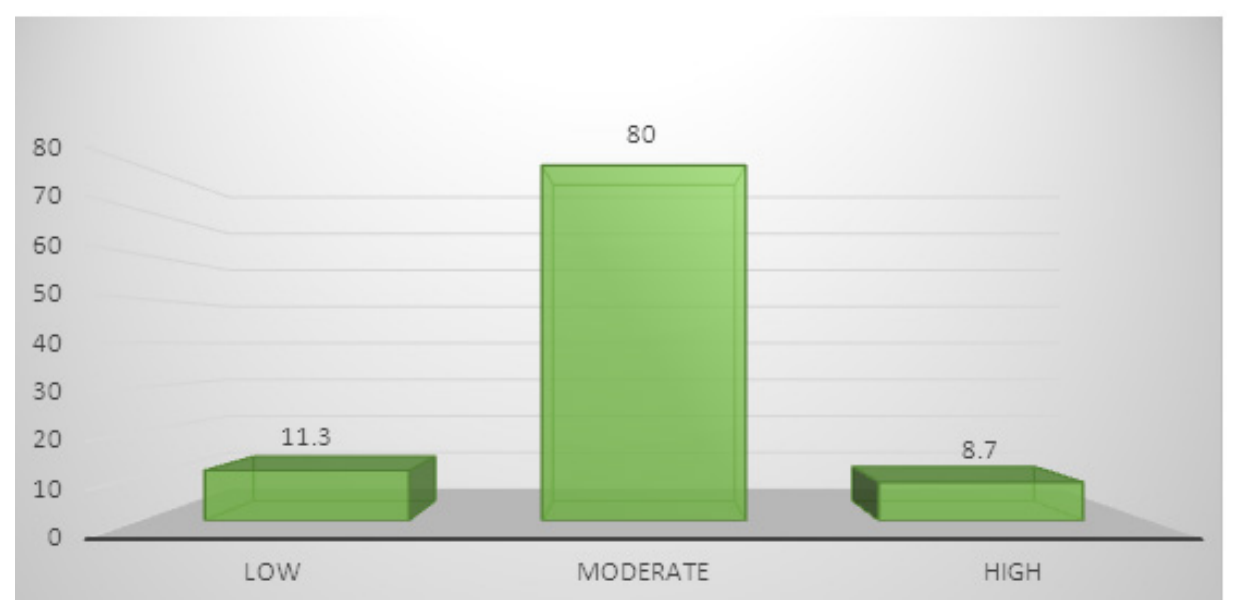

Figure 1. Federal universities' staff perception of NUC performance Of its accreditation process

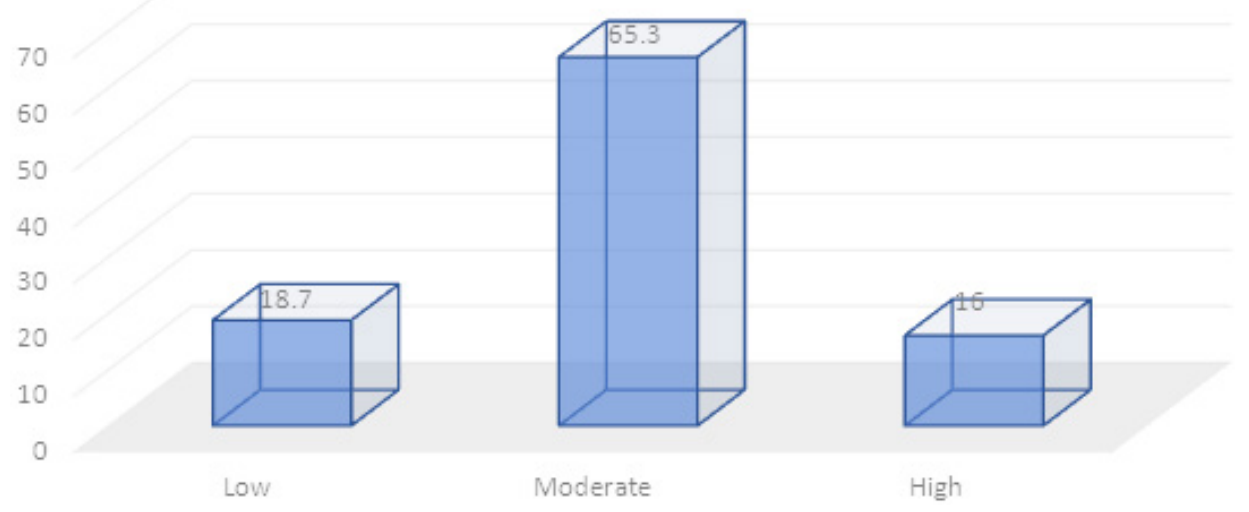

figure 2. State universities' staff perception of NUC performance Of its accreditation ROLE

Question 2: What is the state universities' staff perception of the NUC accreditation role?

Table 2. State universities' staff perception of NUC performance of its accreditation process

\begin{tabular}{|c|c|c|}
\hline Lever & f & $\% \%$ \\
\hline $\begin{array}{c}\text { Low: Min-(x - SD) } \\
(\mathbf{1 6 . 0 0}-\mathbf{2 6 . 0 4 )}\end{array}$ & 28 & 18.7 \\
\hline Moderate: (26.05 - 34.57) & 98 & 65.3 \\
\hline $\begin{array}{c}\text { High: (x+ SD) } \\
(\mathbf{3 4 . 5 8}-\mathbf{4 4 . 0 0 )}\end{array}$ & 24 & 16.0 \\
\hline
\end{tabular}

To answer the question, state universities respondents' scores on NUC accreditation role was computed using Section B of the 'ARQINUS' questionnaire. The mean scores and the standard deviation were used to categorize the subjects into three groups representing levels of performance. Using the mean score of 16.00 and standard deviation of 26.04, respondents whose scores ranged between the minimum scores of 16.00 and the difference between the mean and standard deviation (X-SD) were grouped into 'Low' level performance which gives (Low: 16.00-26.04). Respondents whose scores ranged from the sum of mean and standard deviation and the maximum score of (44.00) were grouped as 'High' i.e. (34.58-44.0). "The moderate' level of performance constituted the respondents whose scores fell between the 'low' and 'high' level (26.05-34.57). The findings revealed that the NUC performance of its accreditation role was at a moderate level with $65.3 \%$ of the respondents adjudging the NUC' performance as moderate. The result is presented in table 2 and graphically represented in figure 2 .

Question 3: What is the NUC level of performance of its accreditation role?

In order to answer this question, respondents scores on NUC accreditation role on the 'ARQINUS' questionnaire was computed. The mean scores and the standard deviation were used to categorize the subjects into three groups representing levels of performance. Using the mean score and standard deviation, respondents whose scores ranged between the minimum scores of 14 and the difference between the mean and standard deviation (X-SD) were grouped into 'Low' level performance i.e. 14 - (29.27-4.64) which gives (Low: 14.00-24.63). Respondents whose scores ranged from the sum of mean and standard deviation and the maximum score of (44.00) were grouped as 'High' i.e. $(29.27+4.64)-44.00$ equals $(33.91-44.0)$. "The moderate' level of performance constituted the respondents whose 
scores fell between the 'low' and 'high' level (42.64-33.90). The findings revealed that the NUC performance of its accreditation role was at a moderate level with $73.0 \%$ of the respondents adjudging the Commission' performance as moderate. The result is presented in table 3 and graphically represented in figure 3.

Table 3. NUC Performance of its Accreditation Role.

\begin{tabular}{|c|c|c|}
\hline Level of performance & f & $\mathbf{\%}$ \\
\hline Low: Min - (X - SD) & 33 & 11.0 \\
\hline Moderate: 24.64 - 33.90 & 219 & 73.0 \\
\hline High: (X + SD) - Max & 48 & 16.0 \\
\hline
\end{tabular}

Question 4: What is the level of quality of the educational inputs?

In order to answer this question, respondents' scores on 'Quality of Inputs' in (ARQINUS) was computed and compared. The mean scores on the quality of inputs and the standard deviation were used to categorize the subjects into three groups representing levels of quality. Using the mean score of 37.44 and standard deviation of 7.01, respondents whose scores on the quality of inputs ranged between the minimum scores of 18 and the difference between the mean and standard deviation (X-SD) were grouped into 'Low' level performance i.e. 18.00 - $(37.44-7.01)$ which gives (Low: 18.00 - 30.43). Respondents whose scores ranged from the sum of mean and standard deviation and the maximum score of (57.00) were grouped as 'High' i.e. $(37.44+7.01)-57.00$ equals $(44.45-57)$. "The moderate' level of performance constituted the respondents whose scores fell between the 'low' and 'high' level (30.44-44.44). The findings revealed that the University staff' perception of the quality of Nigerian university education was moderate with $67.7 \%$ of the respondents adjudging the level of quality of Nigerian University education as moderate. The findings are presented in table 4 and graphically represented in figures 4 .

Table 4. Quality of Educational Inputs.

\begin{tabular}{|c|c|c|}
\hline Level of quality of inputs & f & \% \\
\hline Low: Min - (X - SD) & 42 & 14.0 \\
\hline Moderate: 83.42 - 122.77 & 203 & 67.7 \\
\hline High: (X + SD) - Max & 55 & 18.3 \\
\hline Total & 300 & 100 \\
\hline
\end{tabular}
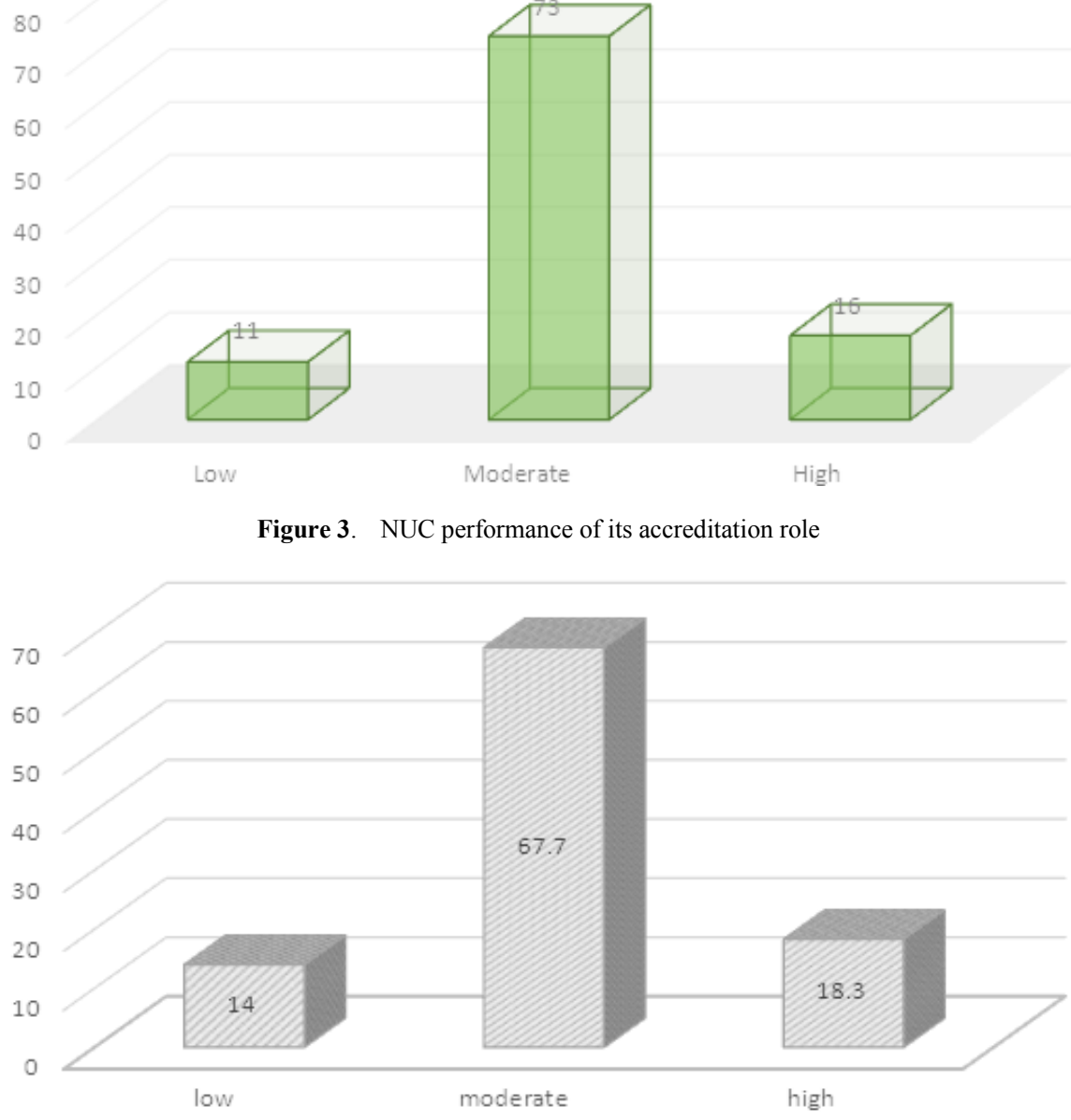

Figure 4. Quality of Educational Inputs 


\section{Testing of Hypotheses}

\section{Hypothesis 1}

There is no significant difference between the perception of Federal and State Universities' staff on NUC performance of its accreditation role.

Mean scores of subjects (Federal and state Universities staff) on the perception of NUC performance of its accreditation process were computed and compared for statistical significance using t-test statistics at 0.05 level of significance. The result is presented in Table 5.

Table 5. t-test showing the perception of Federal and State Universities' staff on NUC accreditation role.

\begin{tabular}{|c|c|c|c|c|c|c|}
\hline Group & N & Mean & SD & Df & t-cal & t-table \\
\hline State & 150 & 30.31 & 4.27 & \multirow{2}{*}{298} & $3.987 *$ & 1.960 \\
\cline { 1 - 5 } Federal & 150 & 28.23 & 4.78 & & & \\
\hline
\end{tabular}

Table 5 showed that $\mathrm{t}$-cal of 3.987 is greater than t-table of 1.960 at 0.05 level of significance. The null hypothesis is rejected. This implies that there is significant difference between the perception of federal and state universities' staff on NUC performance of accreditation role.

\section{Hypothesis 2}

Ho: There is no significant relationship between NUC performance of its accreditation role and the quality of educational inputs into Nigerian university system.

In order to test the hypothesis, scores on NUC performance of its accreditation role and quality of the educational inputs into Nigerian university system were computed and subjected to statistical analysis using Pearson Product Moment Correlation at 0.05 level of significance. The result is shown in table 6 .

Table 6. Pearson Correlation Analysis on NUC Performance of its Accreditation role and Quality of Educational Inputs

\begin{tabular}{|c|c|c|c|c|c|}
\hline Level & N & Mean & SD & r-cal & r-table \\
\hline $\begin{array}{c}\text { Performance of } \\
\text { NUC } \\
\text { accreditation }\end{array}$ & 300 & 29.27 & 4.64 & 0.518 & 0.195 \\
\hline $\begin{array}{c}\text { Quality of } \\
\text { Educational } \\
\text { inputs }\end{array}$ & 300 & 37.44 & 7.01 & & \\
\hline
\end{tabular}

$* \mathrm{P}<0.05$ (Significant result)

Table VI shows that r-calculated of (0.391) was greater than r-table of (0.195) at 0.05 level of significance. Hence the null hypothesis was rejected. This implies that there was a significant relationship between the quality of the educational inputs and NUC performance of its accreditation role.

\section{Discussion}

The finding of the study revealed that the NUC performance of its accreditation role was not as bad as portrayed by most of the stakeholders in education, as it revealed a moderate level. The federal and state university staff respondents also adjudged the NUC performance of its accreditation process as moderate with $80 \%$ and $65.3 \%$ respectively. The finding negated Okwuofu and Aminu (2013)'s report, Okojie (2013) and Akinyanju (2012) submission that the National Universities Commission has failed to reposition the nation's universities.

The finding also contradicted the submission of Amaka (2012) when he remarked about the fraud and self-deception with regard to accreditation processes of the NUC, which according to him, had led to the establishment of some state universities for ego and political reasons without proper assessment. Although the established moderate level of NUC performance of its accreditation role may not be good enough for the system as rightly noted by UNESCO (2005) when it posited that the success of education should be assessed according to what was hoped for or aimed at in advance and not solely on the amount or quality of the results which may emerge in the end.

The study also revealed a moderate level of quality of the educational inputs, which corroborated Belo-Osagie (2012) reports of the NEEDS Assessment Committee on Nigerian universities. There was a significant difference between the perception of federal and state universities' staff on NUC performance of accreditation role. A significant relationship between the quality of educational inputs and NUC performance of its accreditation role was also established by the study. The established moderate level of quality of the educational inputs and the moderate level of NUC performance of its accreditation role was an indication that a better performance of NUC accreditation role would yield a corresponding quality of educational inputs.

\section{Conclusions}

Conclusively the study revealed that the NUC performance of its accreditation role was not as bad as some stakeholders in Nigerian university education have perceived it to be. However, the moderate level of NUC performance of its accreditation role and the moderate level of quality of educational inputs established by the study was an indication that the quality of the educational inputs could improve with improve in NUC performance of its accreditation role. Hence the need for accreditation agencies to carry out their role strictly, by ensuring total compliance with set standard.

In general, the study established that the more effective and efficient an accreditation agency is, the higher the quality of the educational inputs and the overall quality of the educational processes. The political and practical implications of this research findings on Nigeria higher education system is reflected in the way the system is funded. The running of the university system no doubt is capital intensive and requires significant investment in providing and maintaining a basic level of infrastructure, on this note funding education below the $26 \%$ UNESCO 
recommendation may have negative impact on the educational system.

\section{Recommendations}

In view of the established findings of the study, the following recommendations were made.

The National Universities Commission as a regulatory body charged with the statutory responsibility of ensuring globally competitive university education in Nigeria, should improve on its accreditation role by giving optimal performance.

\section{Acknowledgements}

The Researcher wishes to express her profound gratitude to Dr. (Mrs) Akomolafe, Comfort Olufunke, who was the Researcher's $\mathrm{PhD}$ supervisor in the Department of Educational Foundations and Management, Ekiti State University, Ado-Ekiti, Nigeria. Her diligent supervision and professional guidance aided the quality of the Ph.D Thesis part of which is being published in this paper.

\section{REFERENCES}

[1] Aboderin, M. (2012, November 13). ICPC, NUC Strengthen War against Corruption in Varsities. The Punch pp. 48.

[2] Ade- Ajayi, J. F. (2003). Position paper presented at the University Stakeholders National Consultative Forum. Abuja: Federal Ministry of Education, March 1-4. pp. 42.

[3] Akinyanju, P. (2012, July 30). Appreciating funding of public universities. The Punch pp. 17.

[4] Amaka, A. (2012). 2012 Education Budget and its Implications (Analysis). Retrieved on 12/08/2013 from http://www.vanguardngr.com/2012/04/2012-education-budg et-and-its-implications-analysis/

[5] Atoyebi, O. and Oyeleke, S. (2013, September 23). ASUU blasts NUC, says strike continues. The Punch, pp. 15.

[6] Awe, A. B. (2009). Ownership as a Function of Compliance with Quality Assurance Measures on Current Academic Programmes in Nigerian Public Universities. Studies in Education 1(1) pp. land 2.

[7] Belo-Osagie, K. (2012, November 15). Varsity without teacher, tools. The Nation pp. 25-27.

[8] El-Khawas, E. (2006). Linking Programme Review to External Scrutiny, International Developments. International
Higher Education. Retrieved from http://www.bc.edu/bo org/avp/soe/cihe/newsletter.com

[9] ESIB, (2005). European Student Handbook on Quality Assurance in Higher Education. Retrieved on 30/07/2013 from http:// www.esib.org/proiect/gap/QA

[10] Fadokun, O (2006). On external quality Assurance in Higher Education: The Need for a paradigm shift. Retrieve from www.merit.unu.edu/MEIDE/papers/2011/1299015629_JF.p df

[11] National Universities Commission (2002). Quality Assurance in Nigerian Universities Vol.1, Ranking of Nigerian Universities according to Performance of their Academic Programmes in 1999 and 2000 Accreditation Exercise. Abuja, NUC.

[12] National Universities Commission (2005). Purported Rejection of State Universities Graduates by Employers of Labour, Monday Memo, November, 4 (45).

[13] National Universities Commission (2006). 2006 Web metric Ranking of World Universities: Matters Arising. Monday Memo NUC, Abuja, 5 (11) pp. 1-10.

[14] National Universities Commission (2007). Quality Assurance and Sustainable University Education in Nigeria. Retrieved from www.aadcice.hiroshima-u.ac.jp/e/publica...

[15] Okebukola, P. A. (2002). Quality Management in Nigerian University Education, A paper presented at the Committee of Vice- Chancellors (CVC) Seminar, Abuja; 9th-13th June.

[16] Punch Editorial Comment, (2013, August 16). Varsities need effective regulation, The Punch Newspaper pp. 22.

[17] Okwuofu, O. and Aminu, Y. (2013, September 23). ASUU insists NUC should be scrapped. The Nation, pp. 6.

[18] Oladosu, A.G.A.S. (2011). Accreditation in Nigerian Universities: The Role of the Academic Planning Officers, Text presented at the Training Workshop for Academic Planning Officers in Nigerian Universities, Abuja 12th-15th July.

[19] Ramon-Yusuf, S. (2003). The Role of the National Universities Commission in Quality Assurance in Nigerian Universities, Abuja. National Universities Commission Monograph Series, 1 (9).

[20] UNESCO (2005). The EFA (Education for All) The Quality Imperative Global Monitoring Report Team printed in France.

[21] Woodhouse, D. (1999). Quality and Quality Assurance, In Jane Knight and Hansde Wit (Eds.), 1999, Quality and Internationalization of Higher Education; Paris, OECD

[22] Uvah, I. I. (2005). Curriculum Development in the Nigerian University System; National Universities Commission, Abuja. Being Lead Paper presented at the 2005 conference of the Nigeria Association for Educational Administration and Planning, Universities of Calabar. 